\title{
Performance evaluation of biomass sorghum in Hawaii and Texas
}

\author{
Manyowa N. Meki ${ }^{a, *}$, Richard M. Ogoshi ${ }^{\mathrm{b}}$, Jim R. Kiniry ${ }^{\mathrm{c}}$, Susan E. Crow ${ }^{\mathrm{d}}$, Adel H. Youkhana ${ }^{\mathrm{d}}$, \\ Mae H. Nakahata ${ }^{e}$, Kerrie Littlejohn ${ }^{f}$ \\ a Texas A \& M AgriLife Research, Blackland Research and Extension Center,720 E. Blackland Road, Temple, TX 76502, United States \\ b Department of Tropical Plants and Soil Sciences, University of Hawaii at Manoa,1955 East-West Road, Honolulu, HI 96822, United States \\ c USDA, Agricultural Research Service, Grassland Soil and Water Research Laboratory,808 E. Blackland Road, Temple, TX 76502, United States \\ d Department of Natural Resources and Environmental Management, University of Hawaii at Manoa,1910 East-West Road., Honolulu, HI 96822, United States \\ e Hawaii Commercial \& Sugar Company, 1 Hansen Road, Puunene, HI 96784, United States \\ ${ }^{\mathrm{f}}$ Department of Geography, University of Hawaii at Manoa, 2424 Maile Way, Honolulu, HI 96822, United States
}

\section{A R T I C L E I N F O}

\section{Keywords:}

Biomass sorghum

Bioenergy feedstock

Enrolment and agricultural practice

Photoperiod sensitive

\begin{abstract}
A B S T R A C T
Although biomass sorghum [Sorghum bicolor (L.) Moench] has been identified as a high yielding bioenergy feedstock crop on the continental USA, there is however lack of conclusive data on its performance in Hawaii (HI). The objectives of this study were to (i) determine the adaptability and productivity of two biomass sorghum hybrids, and (ii) identify the associated crop parameter attributes and environmental factors for high biomass yields. Two comparative trials were conducted, one on Maui island, HI and the other at Temple, Texas (TX). At Temple, the biomass sorghum hybrids responded as expected, growing to heights in excess of $3 \mathrm{~m}$ and producing average biomass yields of $37.4 \mathrm{Mg} \mathrm{ha}^{-1}$. The high leaf area indices (LAI, 7.8-9.8) intercepted over $90 \%$ incident photosynthetically active radiation (PAR) at LAI $>4$, while the computed average light extinction coefficient (k) was 0.48 . An average plant growth rate (PGR) of $189 \mathrm{~kg}$ dry biomass ha ${ }^{-1}$ day- ${ }^{1}$ was achieved, while the average radiation use efficiency (RUE) was $2.75 \mathrm{~g} \mathrm{MJ}^{-1}$. In sharp contrast to the results obtained at Temple, the two sorghum hybrids planted on Maui behaved like photoperiod insensitive short day grain sorghums; lower plant heights $\left(<2.0 \mathrm{~m}\right.$ ), LAI (average, 3.8) and PGR prior to heading (average, $41 \mathrm{~kg} \mathrm{ha}^{-1}$ day- $^{1}$ ), flowered early ( $~ 90$ days after planting), and had aboveground biomass yields reduced by $76 \%$. The study underscored the importance of not only choosing the right bioenergy crop species, but also the suitability of target environments, planting date and management practices. The crop parameters determined at Temple can be incorporated into crop and environmental simulation models such as ALMANAC, EPIC/APEX and SWAT to model various biomass sorghum cropping systems and their associated environmental impacts.
\end{abstract}

\section{Introduction}

The state of Hawaii (HI) depends on imported coal and oil for $95 \%$ of its energy (US DOE, 2015). Unsurprisingly, its residents pay among the highest prices in the USA for gasoline, residential fuel gas, and electricity (Hawaii State Energy Office, 2015). Faced with this energy challenge, HI has aggressively sought alternative and renewable energy resources to reduce this overdependence on imported energy.

Several US federal and private sector funded projects and demonstrations have been conducted to identify appropriate processes and feedstocks that are economically feasible for producing biofuel in Hawaii (Kinoshita and Zhou, 1999). Although sugarcane (Saccharum officinarum L.) is viewed as the ideal sugar-to-ethanol biofuel, its production in $\mathrm{HI}$ has declined significantly since the 1970s. This decline is due to a number of factors that include low prices (due to the phasing out of the USA government's protections that limited foreign imports), competition from artificial sweeteners, and low cost production from such countries as Mexico, Brazil, India, and China (Gaddis, 2013; Meki et al., 2015).The total area under sugarcane today is now less than 16,200 ha from a high of 103,275 ha in the 1930s. The large tracts of fallow agricultural lands which used to be under sugarcane production are now transitioning into diversified crops. Other land has been converted to urban developments but still large tracts of prime land now lie fallow or are under pasture (Kinoshita and Zhou, 1999).

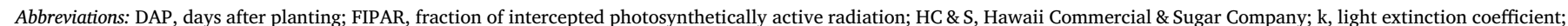

LAI, leaf area index; PAR, photosynthetically active radiation; PGR, plant growth rate; RUE, radiation use efficiency

* Corresponding author.

E-mail addresses: nmeki@brc.tamus.edu (M.N. Meki), ogoshi@hawaii.edu (R.M. Ogoshi), Jim.Kiniry@ARS.USDA.GOV (J.R. Kiniry), crows@hawaii.edu (S.E. Crow), adel@hawaii.edu (A.H. Youkhana), mnakahata@gmail.com (M.H. Nakahata), klittlej@hawaii.edu (K. Littlejohn).

http://dx.doi.org/10.1016/j.indcrop.2017.04.014

Received 28 July 2016; Received in revised form 13 February 2017; Accepted 9 April 2017

0926-6690/ (c) 2017 Elsevier B.V. All rights reserved. 
In HI sugarcane competes with other sectors of the economy for the scarce water resources, and hence the interest in alternatives that optimize water use efficiency. Among the identified potential cellulosic feedstocks, based on their high biomass yields, adaptability to HI conditions, and are relatively drought tolerant, are Napier grass (Pennisetum purpureum) (Kinoshita and Stackmann, 1994) and energycane (Saccharum hyb.) (Alexander, 1985).

Biomass sorghum hybrids have been demonstrated on the continental USA to produce high biomass yields in as few as 90-100 days, and in addition, are relatively drought tolerant (Rooney et al., 2007; Venuto and Kindiger, 2008; Blade Energy Crops, 2010). To our knowledge only one study (Smith et al., 1987) has evaluated the production potential of sweet sorghum as a renewable biofuel resource for HI. The results of Smith et al. (1987) demonstrated that sweet sorghum is far more widely adapted than was anticipated for a plant of tropical origin and certainly has good potential as a biofuel feedstock in HI. While sweet sorghum has high yields of both fiber and fermentable sugars (15-23\%) (Sarath et al., 2008; El Bassam, 2010) biomass sorghums have been bred to specifically maximize cellulosic content (at least $75 \%$ cellulosic content) (EPA, 2015). This study was prompted by the lack of conclusive data on the performance of biomass sorghums [Sorghum bicolor (L.) Moench] in HI and is a component of a bioenergy project whose overall objective was to evaluate the feasibility and sustainability of producing select bioenergy feedstocks in HI (Meki and Kiniry, 2013; Meki et al., 2015).

The hypothesis being addressed in this paper is that although there is great interest in growing biomass sorghums as a bioenergy feedstock in HI, there is still limited scientific information on how they perform under different environmental and management practices. To this end, we conducted a field study at the Hawaii Commercial \& Sugar Company (HC \& S) sugarcane plantation, on the Island of Maui, HI, in collaboration with researchers from the University of Hawaii at Manoa to (i) determine the adaptability and productivity of two biomass sorghum hybrids grown as potential biofuel feedstock crops, and make performance comparisons with a similar trial conducted at Temple, TX, a region known to be well adapted for maximum production of biomass sorghums, and (ii) identify the crop parameters and environmental factors that contribute to the high biomass yields.

\section{Materials and methods}

\subsection{Plant material}

Two Wilbur-Ellis Co. ${ }^{1}$ high biomass sorghum hybrids Integra 405 (I405) and Integra 1990 (I-1990) ${ }^{2}$ were selected for both field experiments conducted at HC \& S, Maui, HI and Temple, TX. When grown at continental USA sites the two hybrids were recognized to have the following characteristics; high biomass yields, drought tolerance, (but are also highly recommended for irrigated production), very tall plants $(3.0-3.6+\mathrm{m})$ with resistance to lodging, early vigor, high forage quality with a low lignin content. Integra-405 has high sugar content (sweet juicy stalks), while I-1990 is of average sugar content. Integra 405 is a late maturing hybrid while I-1990 is photoperiod-sensitive. Photoperiod sensitive sorghums will not flower when grown when the daylength is more than the photoperiod trigger of $12 \mathrm{~h} 20 \mathrm{~min}$, and hence produce high biomass through continued vegetative growth.

\subsection{Study sites and cultural practices}

Field studies were conducted at the HC \& S plantation (lat. $20.89^{\circ} \mathrm{N}$,

\footnotetext{
${ }^{\mathbf{1}}$ http://ag.wilburellis.com/Products/Pages/Home.aspx (Accessed 17 May 2016).

${ }^{2}$ Mention of trade names or commercial products in this article is solely for the purpose of providing specific information and does not imply recommendation or endorsement by the U.S. Department of Agriculture.
}

long. $-156.41^{\circ} \mathrm{W}$; mean elevation $\sim 100 \mathrm{~m}$ asl) and at the USDA ARS, Grassland, Soil and Water Research Laboratory, Temple, TX (lat. $31.09^{\circ} \mathrm{N}$, long. $-97.36^{\circ} \mathrm{W}$; elevation $\sim 219 \mathrm{~m}$ asl) during the 2012 and 2013 growing seasons. At HC \& S, field trials were established on two fields: field (F) 410 which is a high elevation site $(\sim 300 \mathrm{~m}$ asl $)$ and is on a Aridisol (Keahua series), which is a fine, kaolinitic, isohyperthermic Ustic Haplocambid; F718 is a low elevation site ( $\sim 30 \mathrm{~m}$ asl) and is on a Mollisol (Ewa series), which is a fine, kaolinitic, isohyperthermic Aridic Haplustolls (USDA NRCS, 2011). Two elevations were chosen due to previous observations which indicated that although certain bioenergy species such as Napier grass are well adapted and yield well at most elevations, sugarcane and energycane are not well adapted to higher elevations and their yields are much lower (Mae Nakahata and Richard Ogoshi, co-authors, pers. comm.). So the two elevations were chosen so as to assess the performance of the two biomass sorghum hybrids at the two elevations. At Temple, the field trials were conducted on a Vertisol (Houston black clay), which is a fine, smectitic, thermic Udic Haplusterts (USDA NRCS, 2011). A few selected key soil properties of the three soils are presented in Table 1. At HC \& S and Temple, weather data for the study fields was respectively obtained from an on-field and on-station weather station.

At Temple, a completely randomized repeated measures design with three replicates was used. Overall plot sizes were approximately $12 \mathrm{~m}$ by $12 \mathrm{~m}$ to allow for unbiased repeated biomass samplings throughout the growing season. Roundup ( $N$-(phosphonomethyl)glycine, $\mathrm{C}_{3} \mathrm{H}_{8} \mathrm{NO}_{5} \mathrm{P}$ ) herbicide was applied at a rate of $3.51 \mathrm{~L} /$ ha to control weeds a week prior to planting. The field was conventionally tilled (plowing followed by disking) and fertilized with 120 and $30 \mathrm{~kg} \mathrm{ha}^{-1}$ of $\mathrm{N}$ and $\mathrm{P}$ fertilizers, respectively. Fertilization rates were based on data reported in the literature (Blade Energy Crops, 2010; Maughan et al., 2012; Rocatelli et al., 2012; Snider et al., 2011; Undersander et al., 1990). The 2012 and 2013 field plots were established on 19 and 8 April, and final harvests were on 20 and 3 September, respectively. The biomass sorghums were seeded at the recommended seeding rates of 180,000 seeds ha ${ }^{-1}$ (Blade Energy Crops, 2010) using the Great Plains 1510 minimum till grain drill (Great Plains Manufacturing, Salina, KS). To ensure near-optimum growing conditions throughout the growing season, limited supplementary irrigation water of $200 \mathrm{~mm}$ and $150 \mathrm{~mm}$ was applied in 2012 and 2013, respectively.

At HC \& S, the sorghum hybrids were planted in a field previously under sugarcane. A group-balanced block experimental design which included three other candidate bioenergy crops: sugarcane, energycane and Napier grass was used. Fields were subsoiled with a deep ripper (60 cm depth), followed by disc harrowing $(45 \mathrm{~cm})$. Trial plots were established on September 9, 2011, with final harvests on September 11, 2012 (F410) and September 12, 2012 (F718). Experimental plots in both Temple and at HC\&S were replicated three times. At HC\&S individual plots $(15 \mathrm{~m} \times 11 \mathrm{~m})$ consisted of four rows of grass, centered on a drip irrigation line, the distances between rows and drip lines were $0.23 \mathrm{~m}$ and $2.7 \mathrm{~m}$ as described in Meki et al. (2015). This design was used to accommodate the sugarcane infrastructure of drip lines already in place. A pre-emergence herbicide mix containing atrazine (1-chloro-3-ethylamino-5-isopropylamino-2, 4, 6-triazine), 2, 4-D (2, 4-dichlorophenoxyacetic acid), Prowl (( $N$-1-ethylpropyl)-3, 4dimethyl-2, 6-dinitrobenzenamine), Rifle (3, 6-dichloro-2-methoxybenzoic acid), and Velpar (3-cyclohexyl-6-dimethylamino-1-methyl-1, 3, 5triazine-2, $4(1 \mathrm{H}, 3 \mathrm{H})$-dione) was applied to control weeds. Seeds were hand sowed into the rows at a target seeding rate of 143,000 plants $\mathrm{ha}^{-1}$. Although the hand sowed seeding rate at HC \& S was lower than that at Temple, sorghums have the ability to compensate (or self-thin) the plant population through tillering (Snider et al., 2011; Gerik and Neely, 1987), especially under drip and fertigated field conditions. Annual rainfall varied from 250 to $1500 \mathrm{~mm}$ in the irrigated plots $(92 \%$ of total cultivated area). Plants were drip-irrigated weekly as needed to prevent any water stress. The amount of water applied was determined by the plantation's crop production managers who controlled the whole 
Table 1

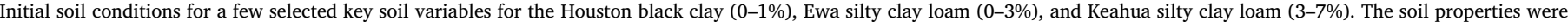
compiled from the USDA NRCS SSURGO database: http://sdmdataaccess.nrcs.usda.gov/http://sdmdataaccess.nrcs.usda.gov/ (accessed March 2016).

\begin{tabular}{|c|c|c|c|c|c|c|c|c|c|c|}
\hline \multirow[b]{2}{*}{ Soil layer } & \multicolumn{3}{|c|}{ Houston black clay $(0-1 \%)$} & \multicolumn{3}{|c|}{ Ewa silty clay loam $(0-3 \%)$} & \multicolumn{4}{|c|}{ Keahua silty clay loam (3-7\%) } \\
\hline & 1 & 2 & 3 & 1 & 2 & 3 & 1 & 2 & 3 & 4 \\
\hline \multicolumn{11}{|l|}{ Soil variable } \\
\hline Depth (m) & $0.01-0.15$ & $0.15-1.12$ & $1.12-2.03$ & $0.01-0.46$ & $0.46-0.99$ & $0.99-1.52$ & $0.01-0.25$ & $0.25-0.84$ & $0.84-1.57$ & $1.57-1.78$ \\
\hline Porosity (mm) & 0.53 & 0.50 & 0.44 & 0.55 & 0.53 & 0.53 & 0.55 & 0.57 & 0.53 & 0.53 \\
\hline Field Capacity (mm) & 0.45 & 0.42 & 0.40 & 0.37 & 0.36 & 0.36 & 0.29 & 0.32 & 0.32 & 0.14 \\
\hline Wilting Point (mm) & 0.32 & 0.30 & 0.28 & 0.23 & 0.22 & 0.22 & 0.18 & 0.21 & 0.21 & 0.10 \\
\hline Soil Water $(\mathrm{mm})$ & 0.43 & 0.40 & 0.38 & 0.34 & 0.33 & 0.33 & 0.26 & 0.29 & 0.29 & 0.13 \\
\hline Saturated Conductivity $(\mathrm{mm} / \mathrm{h})$ & 1.46 & 1.46 & 1.46 & 32.40 & 32.40 & 32.40 & 82.80 & 25.20 & 9.00 & 25.20 \\
\hline $\mathrm{BD} 33 \mathrm{kPA}\left(\mathrm{t} \mathrm{m}^{-3}\right)$ & 1.22 & 1.31 & 1.43 & 1.20 & 1.20 & 1.20 & 1.10 & 1.10 & 1.20 & 1.20 \\
\hline BDD Oven dry soil $\left(\mathrm{t} \mathrm{m}^{-3}\right)$ & 1.22 & 1.31 & 1.43 & 1.25 & 1.26 & 1.26 & 1.15 & 1.15 & 1.26 & 1.34 \\
\hline Sand $(\%)$ & 17 & 17 & 17 & 5.8 & 5.1 & 5.1 & 18.5 & 17 & 27.6 & 23.7 \\
\hline Silt $(\%)$ & 28 & 28 & 28 & 42.2 & 37.9 & 37.9 & 44 & 40.5 & 29.9 & 28.8 \\
\hline Clay (\%) & 55 & 55 & 55 & 52 & 57 & 57 & 37.5 & 42.5 & 42.5 & 47.5 \\
\hline Rock (\%) & 2 & 2 & 4 & 0 & 3 & 3 & 6 & 3 & 3 & 3 \\
\hline $\mathrm{pH}$ & 7.90 & 7.90 & 7.90 & 7.60 & 7.40 & 7.40 & 6.30 & 6.30 & 7.00 & 7.00 \\
\hline CEC $\left(\mathrm{cmol} \mathrm{kg}^{-1}\right)$ & 45.00 & 45.00 & 32.50 & 21.00 & 15.00 & 15.00 & 22.50 & 17.50 & 15.00 & 15.00 \\
\hline Soil organic carbon (\%) & 1.32 & 0.23 & 0.03 & 1.76 & 0.65 & 0.65 & 1.76 & 0.74 & 0.24 & 0.18 \\
\hline
\end{tabular}

plantation drip irrigation system. A total of $640 \mathrm{~mm}$ was applied during the study period. Liquid urea (46-0-0) and phosphorus fertilizers were applied monthly through the drip irrigation system at rates of $345 \mathrm{~kg} \mathrm{~N} \mathrm{ha}^{-1}$ and $45 \mathrm{~kg} \mathrm{P} \mathrm{ha}^{-1}$. The timing and rate of fertilizer application were based on HC \& S plantation practices and the need to accommodate the fertilizer requirements of the two-year cycle sugarcane.

\subsection{Plant growth measurements}

At Temple aboveground biomass measurements and sampling began 35 and 45 days after planting (DAP) in 2012 and 2013, respectively. Thereafter biomass measurements and sampling occurred every two weeks. Plant height was measured before each biomass harvest, from the ground to the tip of the longest leaf. Biomass samples were collected from a randomly chosen representative area of $0.5 \mathrm{~m} \mathrm{x} 1 \mathrm{~m}=0.5 \mathrm{~m}^{2}$, avoiding previously sampled areas or plot edges. Three samples were collected at each harvest. A total of seven biomass harvests were made for each year. The photosynthetically active radiation (PAR) intercep- tion was measured with a $0.8 \mathrm{~m}$ AccuPAR LP-80 Ceptometer (Decagon, Pullman, WA) as described in Meki et al. (2015). In the laboratory, the samples were weighed and then separated into stem, leaves and panicle (head), when present. The leaf area was determined with a LiCor LI3100 leaf area meter (LiCor Inc., Lincoln, NE) and used to determine leaf area index (LAI). Dry biomass was measured after drying all harvested plant materials in a forced-air drying oven at $70{ }^{\circ} \mathrm{C}$ to constant weight which also allowed the determination of percent moisture content at final harvest. The light extinction coefficient $(k)$ values for each biomass harvest stage were calculated using Beer's law (Monsi and Saeki's, 1953):

$k=[\mathrm{Ln}(1.0-\mathrm{FIPAR})] / \mathrm{LAI}$

where FIPAR is the fraction of intercepted photosynthetically active radiation. The radiation use efficiency (RUE) of the two hybrids was calculated as the slope of the regression equations for dry biomass as a function of accumulated intercepted PAR.

Similar procedures were used to take plant growth measurements from F410 and F718 HC \& S: biomass yield (stem, leaves and head), leaf
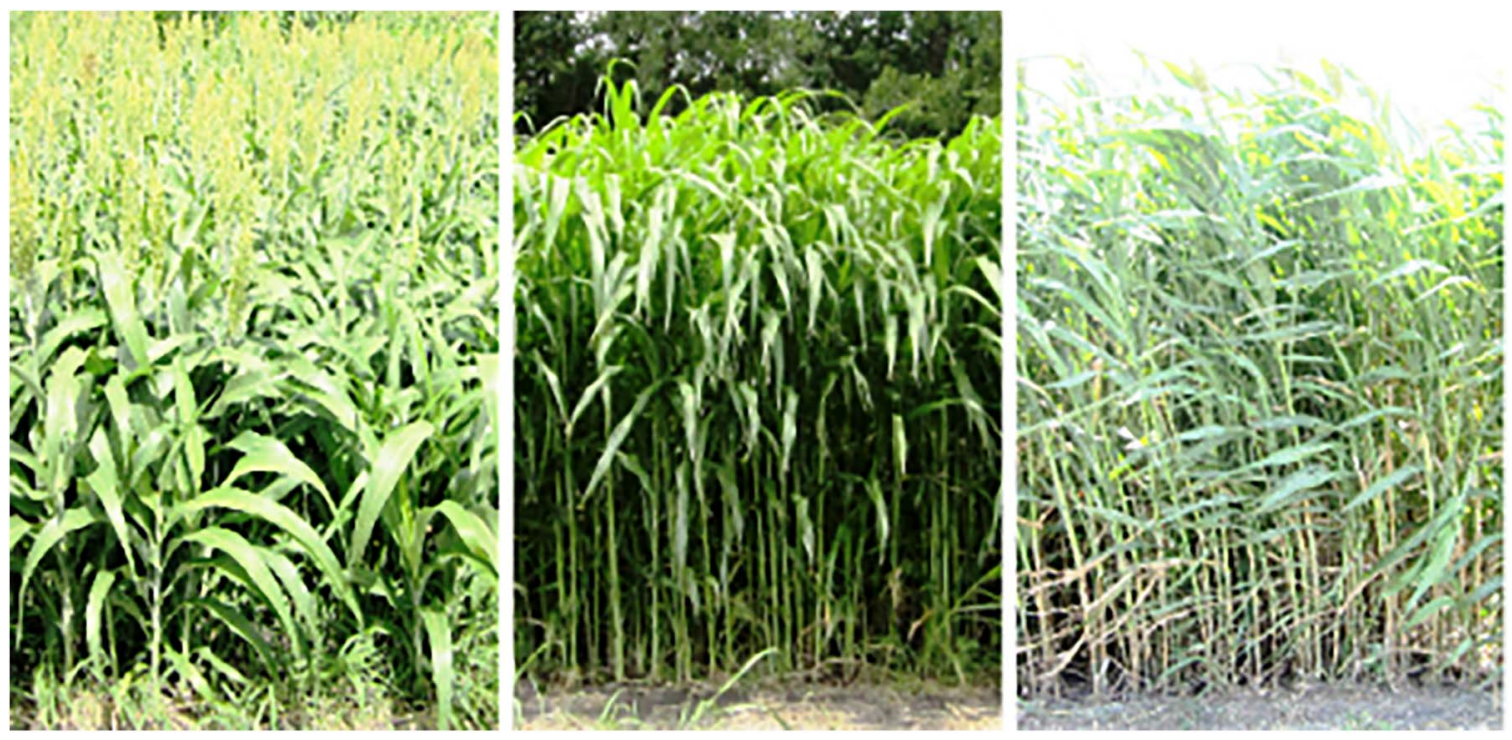

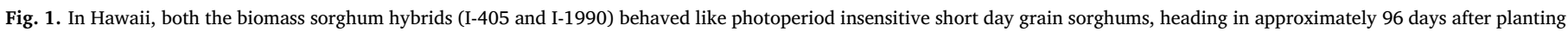
(DAP) (left photo). In Texas, the two hybrids continued to grow vegetatively (middle photo), and only the late maturing I-405 hybrid flowered late in the season (right photo). 


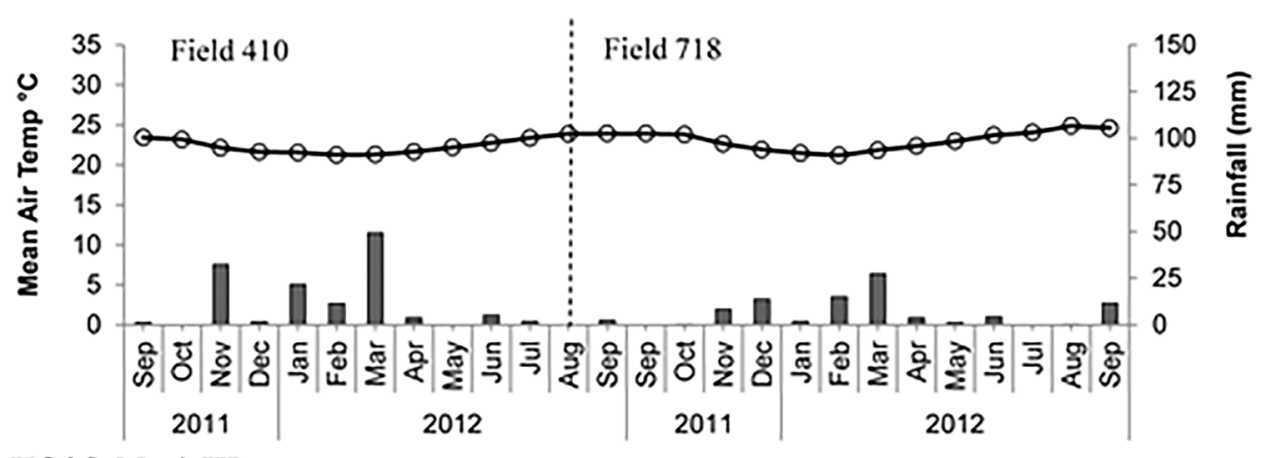

HC\&S, Maui, HI

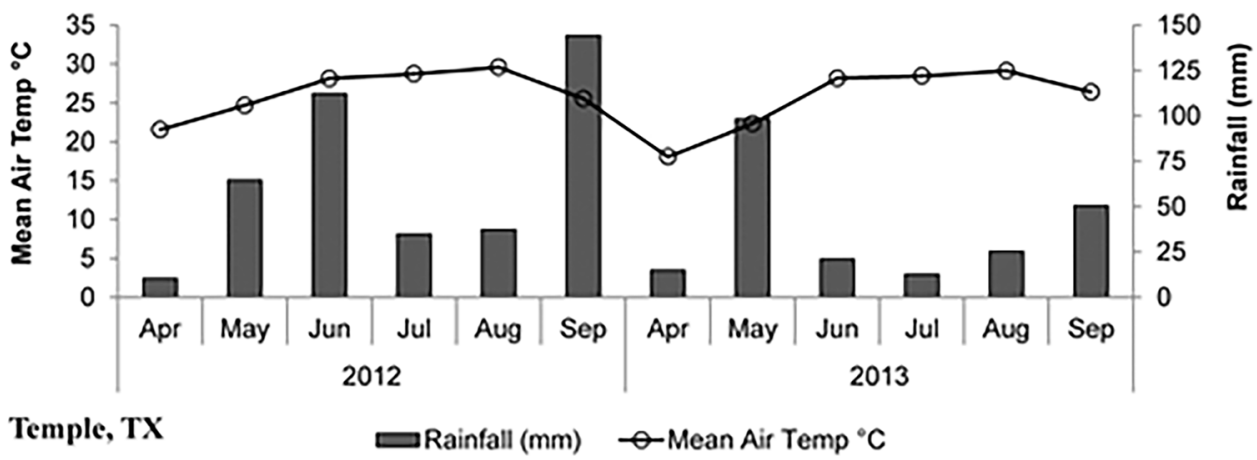

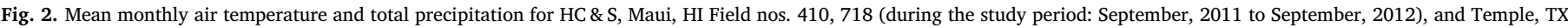
(during the study periods: April to September, 2012 and 2013).

area for LAI determinations, plant height and percent moisture content. Only a limited number of field measurements could be taken in Hawaii due to labor bottlenecks and costs. Field measurements were taken every three months during a 12 month period.

\subsection{Data analysis}

Statistical analyses for the two experimental sites were performed

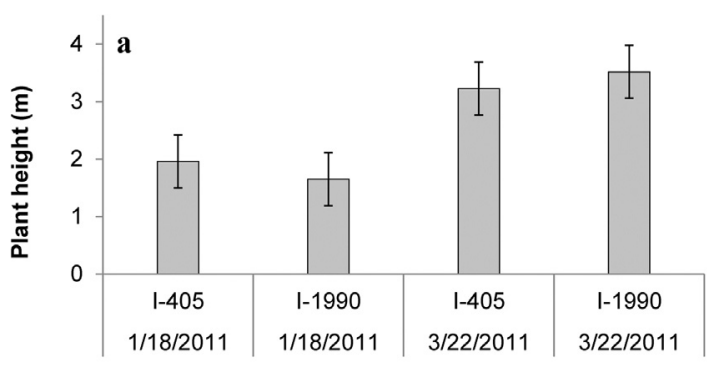

Effects of planting date/daylength on plant height

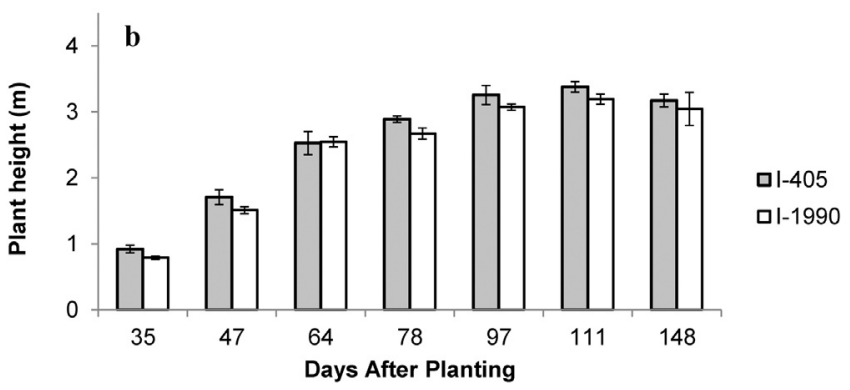

Fig. 3. (a) Effects of planting date/daylength on hybrids I-405 and I-1990 plant heights at HC \& S, Maui, HI, during the 2011 growing season, and (b) plant height measurements for I-405 and I-1990 at Temple, TX, averaged across the 2012 and 2013 growing seasons. Vertical bars represent the standard error of the means of the measured data. using SAS version 9.3 (SAS Institute, 2011). Standard and repeated Measures ANOVA using SAS PROC GLM was performed on the measured and derived variables: plant height, dry biomass (stem, head and leaves), percent moisture content, LAI, $k$, FIPAR, and RUE. The SAS REG procedure was used to conduct regression analyses to describe the relationship between aboveground dry biomass vs. accumulated intercepted PAR. Differences between means of measured and derived variables were separated by standard errors for the mean at $P<0.01$.

\section{Results and discussion}

\subsection{Temperature, precipitation, and irrigation}

The mean monthly air temperature and total precipitation at HC \& S during the study period (September, 2011 to September, 2012) for Field 410 were respectively, $22^{\circ} \mathrm{C}$ and $112 \mathrm{~mm}$ (Fig. 2 ). The dotted line separates the weather data for Field 718 whose mean monthly air temperature and total precipitation were respectively, $23^{\circ} \mathrm{C}$ and $88 \mathrm{~mm}$. The mean monthly air temperature and total precipitation for Temple during the study periods were respectively, $26^{\circ} \mathrm{C}$ and $404 \mathrm{~mm}$ (2012), and $25^{\circ} \mathrm{C}$ and $223 \mathrm{~mm}$ (2013).

\subsection{Plant height}

Differences in plant height and developmental stages of the biomass sorghum hybrids grown at HC \& S and Temple are shown in Figs. 1 and 3. At HC \& S I-405 and I-1990's final heights were dependent on the date of planting (Fig. 3a). When I-405 and I-1990 were planted before March i.e. daylength hrs $<12 \mathrm{~h} 20 \mathrm{~min}$, the biomass sorghums behaved like photoperiod insensitive short day grain sorghums. The hybrids had initiated flowering by the first biomass harvest date (96 DAP) (Figs. 1a and 5b) and only grew to final heights of less than $2 \mathrm{~m}$. In contrast, when the two hybrids were planted after March i.e. when daylength hrs exceeded $12 \mathrm{~h} 20 \mathrm{~min}$ (Fig. 3a) their plant heights exceeded $3.0 \mathrm{~m}$.

At Temple, I-405 and I-1990 were not significantly different in plant 
a. HC\&S, Maui, HI

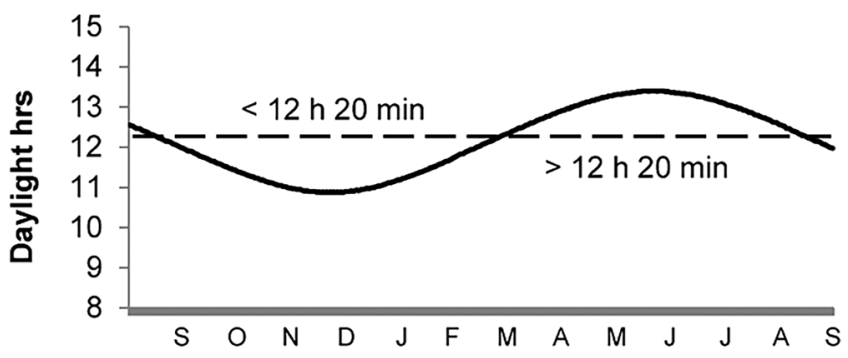

b. Aiea (Kunia), Oahu, HI
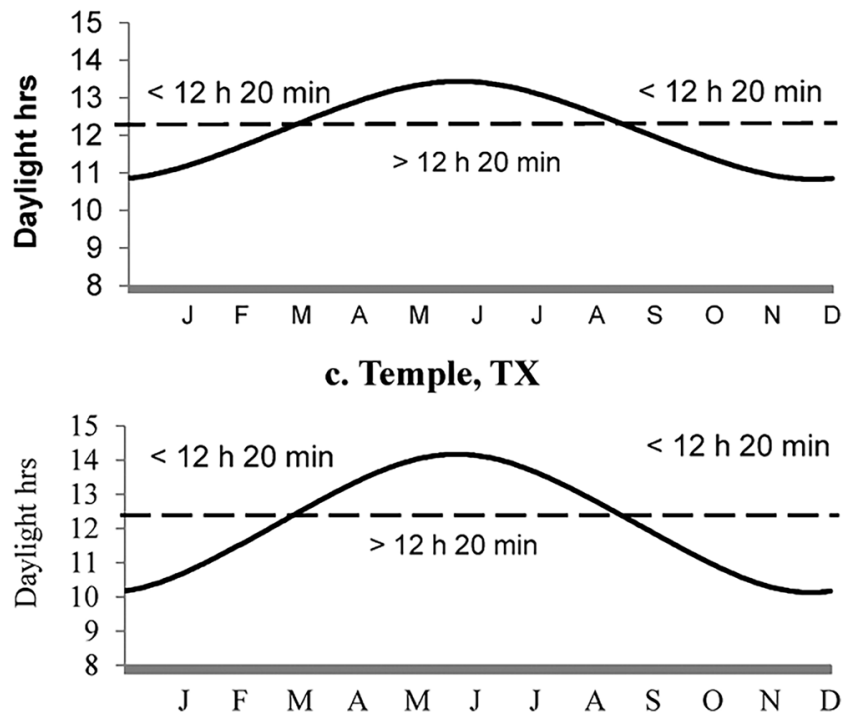

Fig. 4. (a) Daylight hours at HC \& S, Maui, HI, (b) Aiea, Oahu, HI, and (c) Temple, TX, during the study periods.

height $(P<0.01)$ across the two growing seasons: 2012 and 2013, reaching maximum plant heights of $3.38 \mathrm{~m}$ and $3.19 \mathrm{~m}$, respectively (averaged across years) (Fig. 3b). Overall the plants' prolonged vegetative growth contributed to the high plant heights. Biomass sorghum plant heights exceeding $3 \mathrm{~m}$ have also been reported in several studies (Maughan et al., 2012; Rocateli et al., 2012; Carmi et al., 2006; Sakellariou-Makrantonaki et al., 2007).

The daylength effect assumption is corroborated by the results of a study by Smith et al. (1987) at Aiea, HI ( $23^{\circ} \mathrm{N}$ latitude) and the response of other measured traits at HC \& S. In a 4-year varietal study of four to six sweet sorghum cultivars, Smith et al. (1987) recorded an average maximum plant height of $3.88 \mathrm{~m}$ and a biomass yield of $29.61 \mathrm{Mg} \mathrm{ha}^{-1}$. Although plant dates are not mentioned in the Smith et al. (1987) paper, it is most likely the two experiments conducted in 1981 and 1983 were planted during the time when daylength hrs were greater than the photoperiod trigger of $12 \mathrm{~h} 20 \mathrm{~min}$ (March 30 and September 1) (Fig. 4b). At Temple, and for most other places on the continental USA, biomass sorghums are planted when daylength hrs exceed the photoperiod trigger of $12 \mathrm{~h} 20 \mathrm{~min}$ (Fig. 4c).

Although no significant lodging was observed in I-405 and I-1990 both at Temple and HC \& S, Smith et al. (1987) noticed significant lodging in nearly all the cultivars which had plant heights that exceeded $3 \mathrm{~m}$. Serious problems associated with the lodging of tall plants can lead to reduced biomass yields especially in places such as Hawaii which sometimes experience adverse weather conditions of high winds. More research is needed to determine if it is possible to develop biomass sorghum types of medium height but with wider stem diameters to maintain the high biomass yield.

\subsection{Dry biomass yields}

The total, stem, leaves and head dry biomass yields differed greatly between hybrids and years during the 2012 and 2013 growing seasons at Temple, TX (Fig. 5a). There were significant biomass yield differences $\left(P^{<} 0.01\right)$ between the I-405 and I-1990, across harvest dates and the 2012 and 2013 growing seasons. The two hybrids performed as expected of high biomass sorghums, with I-405 and I-1990 reaching maximum biomass yields of $37.9 \mathrm{Mg} \mathrm{ha}^{-1}$ and $36.9 \mathrm{Mg} \mathrm{ha}^{-1}$ in 2013 , respectively (Fig. 5a). These biomass sorghum yields are comparable to those reported in College Station, TX by Miller and McBee (1993), Rooney et al. (2007), and Olson et al. (2012). Despite the supplemental irrigation at Temple, overall dry biomass yields were $50 \%$ lower in 2012 due to the comparably lower rainfall during the rapid growth phase of biomass sorghum.

Both I-405 and I-1990 initially had a rapid accumulation of leaf biomass before it was overtaken by stem biomass at about 50 DAP. By the time of the final harvest (148 DAP) stem biomass comprised approximately $73 \%$ of the total dry biomass. In a similar study, Olson et al. (2012) reported an end of season stem biomass partitioning of 83\%, while Smith et al. (1987) reported a percent stalk harvest weight of $79 \%$. Flowering in I-405 resulted in a $7 \%$ and $25 \%$ decline in total biomass yield in 2012 and 2013, respectively. Despite the flowering (approximately 78 and 97 DAP in 2012 and 2013, respectively), the grain yield of I-405 at the final harvests was only $2.3 \%$ of the total biomass. As expected I-1990 did not flower at all continuing to grow vegetatively until the final harvest at 148 DAP.

In sharp contrast to the results obtained at Temple, overall dry biomass yields of both I-405 and I-1990 were 76\% lower at HC \& S (Figs. 1 and 5b). Interestingly, sweet sorghum biomass yields at Aiea, HI (29.61 $\mathrm{Mg} \mathrm{ha}^{-1}$ ) (Smith et al., 1987) were within the range for biomass sorghum yields reported for the continental USA and other regions of the world (Habyarimana et al., 2004a,b; Ra et al., 2012; Ceotto et al., 2013). Despite there being no significant differences $\left(P^{<0.01)}\right.$ between I-405 and I-1990 biomass yields, the hybrids at HC \& S had a growth pattern which was distinctively different from that at Temple. Similar to the plant height responses, the growth pattern seemed to have somewhat been influenced by the date of planting and daylength hrs during emergence. Although both hybrids were planted on September 9 when the daylength hrs were $12 \mathrm{~h} 24 \mathrm{~min}$ (Fig. 4a), the daylength only four days after planting was less than the photoperiod trigger hrs of $12 \mathrm{~h}$ $20 \mathrm{~min}$. Even though I-405 is considered late maturing and I-1990 photoperiod-sensitive, both hybrids behaved like photoperiod insensitive short day grain sorghums. The hybrids initiated flowering by the first biomass harvest date (96 DAP) (Figs. 1 and 5b). Planting biomass sorghums during inappropriate daylength periods will trigger early flowering and heading, and will result in low biomass yields (Blade Energy Crops, 2010). Heading diverts assimilates from the vegetative parts, primarily stems and leaves to the grain resulting in low biomass accumulation and overall biomass yields. Even though both I-405 and I1990 were still at the soft dough stage (Zadoks et al., 1974) when they were harvested at 96 DAP they already had reduced biomass accumulation and had started to senesce resulting in a drop in biomass yield at the second harvest date (172 DAP). Similar results have been reported for grain sorghum by Gutjahr et al. (2013) in Mali and by Olson et al. (2012) in College Station, TX.

After the second biomass harvest date (172 DAP) daylength started to increase (Fig. 4a), while there was also a slight increase in the mean daily air temperature (Fig. 2). Given these conditions plus the continued drip irrigation and fertigation, both hybrids started tillering which increased total biomass accumulation throughout the rest of the growing period. While the growth pattern and biomass yields of I-405 and I-1990 in F718 are very much similar, their growth responses in F410 are slightly different, in particular at the last harvest (368 DAP) at which I-1990 had a 59\% higher biomass yield than I-405. In F410, and although small, I-1990 flowered and produced some head at the 368 

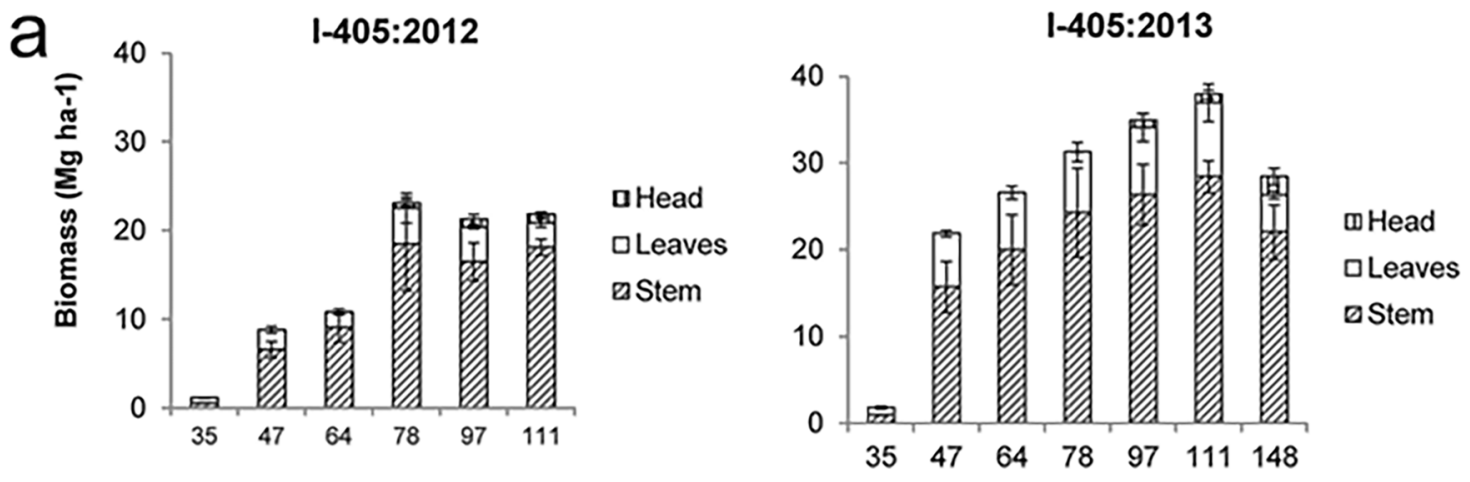

I-1990: 2012

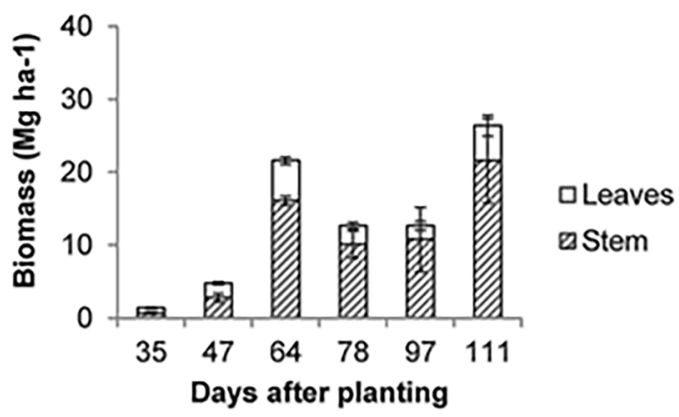

I-1990: 2013

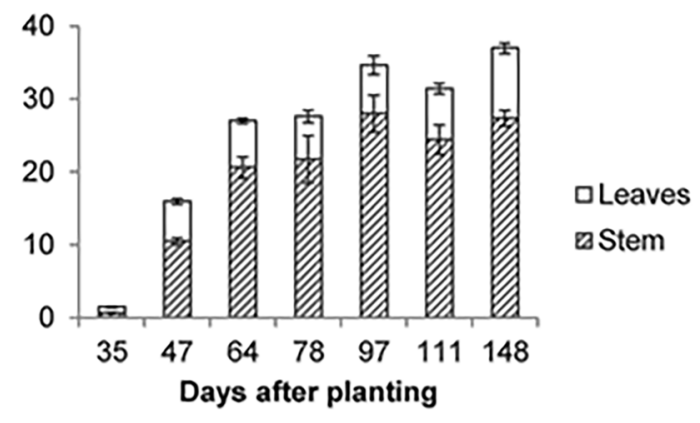

b

F410:I-405

F718:I-405
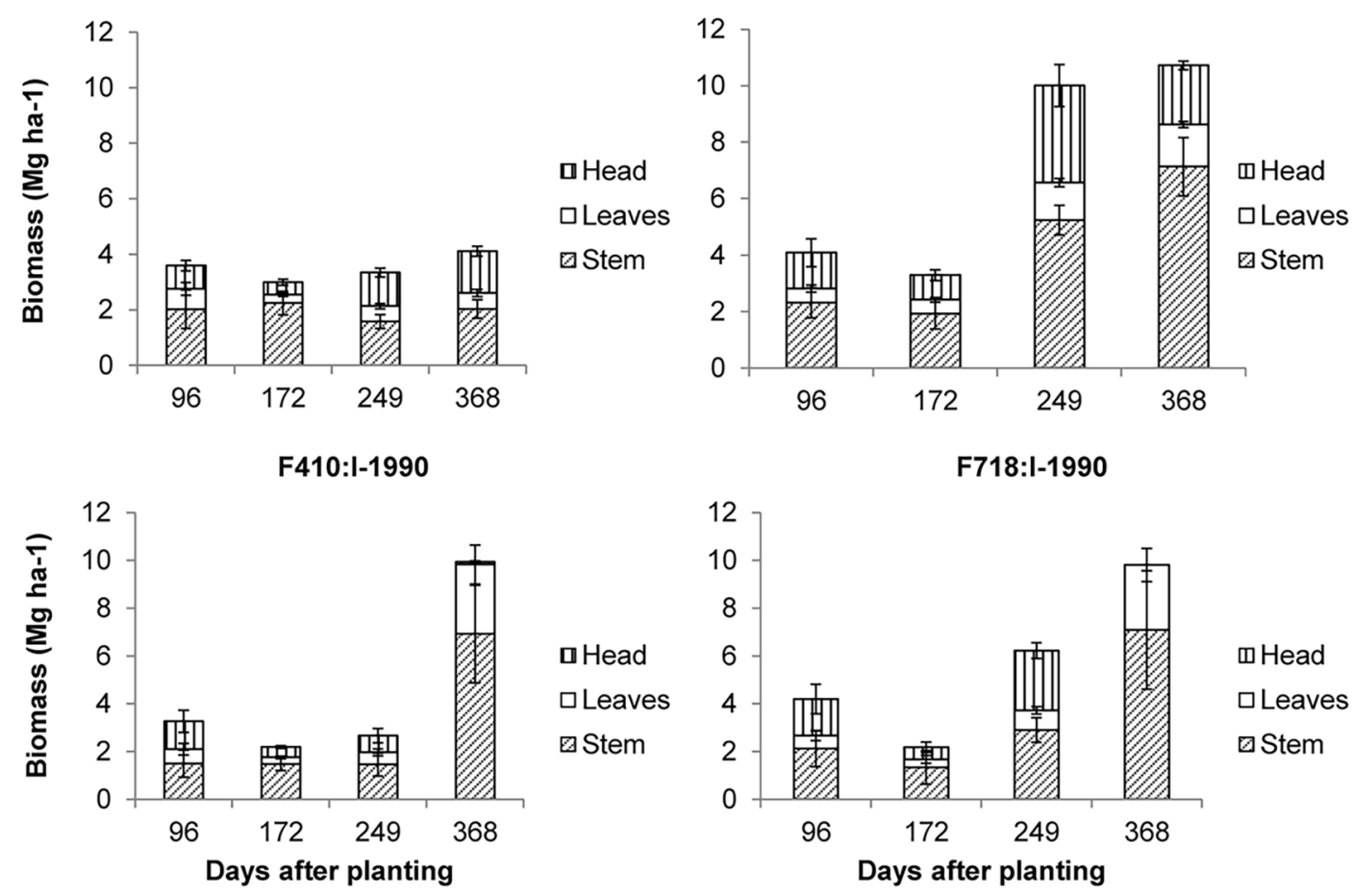

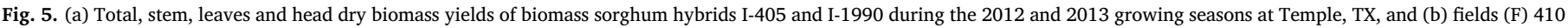
and 718 at HC \& S, Maui, HI. Vertical bars represent the standard error of the means of the measured data.

DAP harvest, while in F718, I-1990 did not produce any head at all. We could not find any reasonable explanation of this difference, except to speculate that it could have been due to sampling errors. We did however notice that overall, plants did not all flower and head at the same time, raising questions of the genetic purity of the hybrid.

Although the total accumulated biomass at HC \& S was much lower than that at Temple, grain biomass partitioning for both hybrids was much higher, which on average was $30 \%$ for I-405 and $26 \%$ for I-1990, 


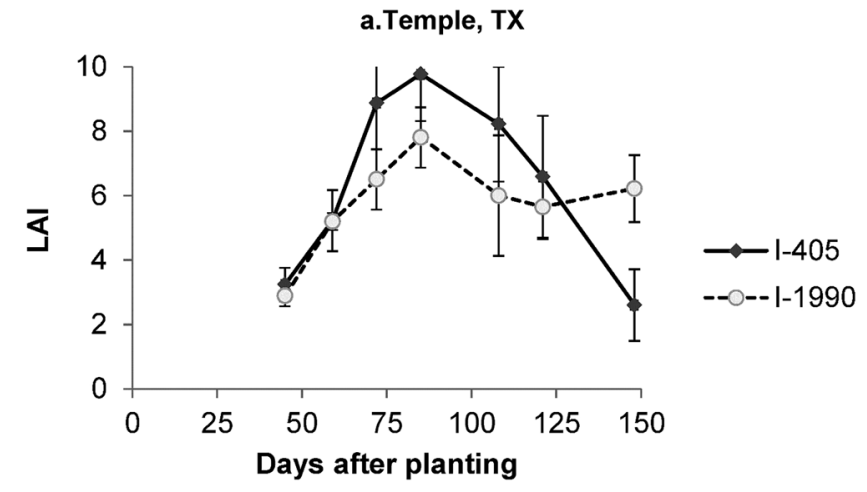

b. HC\&S, Maui, HI

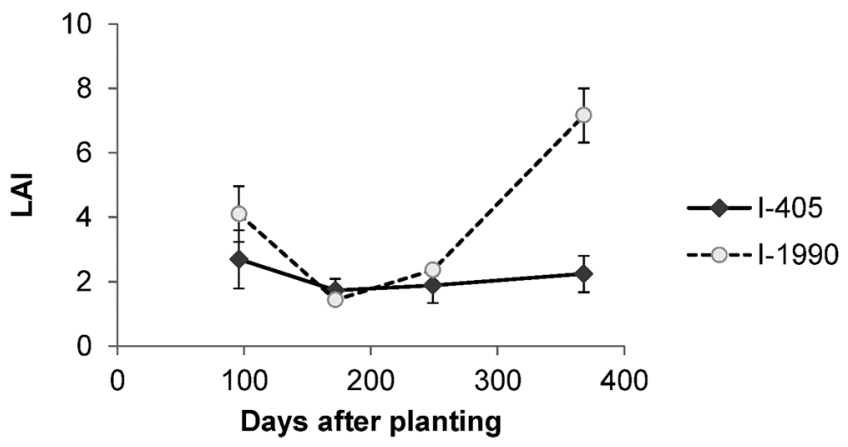

Fig. 6. (a) Measured leaf area index (LAI) at Temple, TX and (b) HC \& S plantation, Maui, HI. Vertical bars represent the standard error of the means of the measured data.

respectively. Again partitioning of stem biomass to total biomass increased over time, and was similar for both hybrids and respectively reaching peak values of $58 \%$ (I-405) and $71 \%$ (I-1990) at the last harvest (368 DAP).

While high biomass yields are deemed essential for lignocellulosic bioenergy feedstock production, a study by Mohammed et al. (2014) showed that sometimes less harvested biomass could produce more energy, with the added advantages of reduced biomass ash, soil nutrient uptake, transportation costs, and storage. However, the biomass yield reduction due to the inappropriate date of planting and daylength photoperiodic effects in $\mathrm{HI}$ was such that biomass quality alone would not offset the bioenergy output from the high biomass yields obtained in Texas. Both direct combustion and cellulosic ethanol production from high biomass sorghum requires the maximization of cellulosic biomass yields (Rooney et al., 2007; Carpita and McCann, 2008).

Although it can be argued that the low biomass yields in $\mathrm{HI}$ were due to the lower seeding rates, studies by Snider et al. (2011) showed

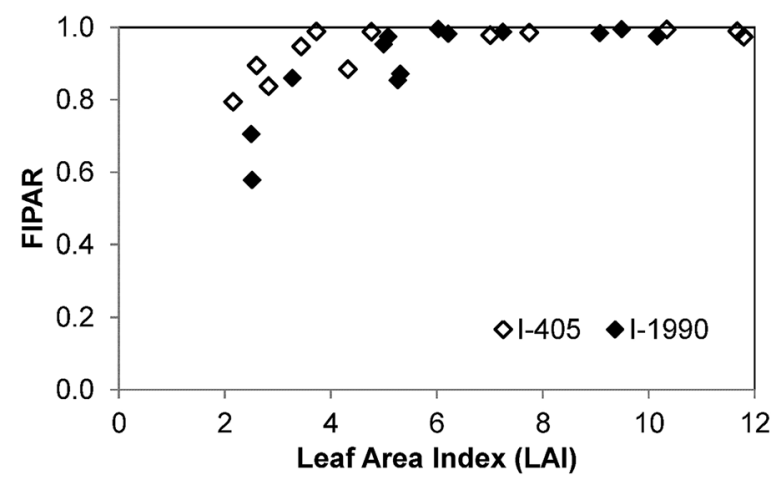

Fig. 7. Relationship between the fraction of intercepted photosynthetically active radiation (FIPAR) and leaf area index (LAI) of biomass sorghum hybrids I-405 and I1990 at Temple, TX. that increasing seeding rate from 116,000 to 291,000 seeds ha $^{-1}$ did not affect biomass sorghum yields. High seeding rates produce tall plants with thinner stem diameters, while lower seeding rates produce shorter plants with thicker stem diameters (Blade Energy Crops, 2010; Snider et al., 2011). Snider et al. (2011) also noticed that under low seeding rates, stem density was higher than the number of seeds sown, suggesting that tillering compensated for the low seeding rates. Similarly, Gerik and Neely (1987) observed increased tiller production under low plant densities in grain sorghum, therefore suggesting that plant compensation via tillering may maintain stem density in some instances.

\subsection{Leaf area index (LAI) and light interception}

The LAI, light interception and dry biomass data collected at Temple were used to derive some of the crop parameter attributes of high biomass sorghums. For most crops LAI is a key driving variable for plant growth rate (PGR) and biomass accumulation especially before full crop canopy closure when light interception by individual leaves is at its maximum (Evans, 1993). In addition LAI determines the amount of intercepted radiation and hence RUE, which in turn is an important function that is basic to plant growth. A linear relationship between LAI and PGR was reported by Tsuni and Fujisi (1965) and Meki et al. (2015). There were significant differences $\left(\mathrm{P}^{<0.01)}\right.$ in LAI between I405 and I-1990 at Temple. Averaged across the two years maximum LAI values for I-405 and I-1990 were 9.8 and 7.8, respectively (Fig. 6a). Similar biomass sorghum LAI values have been reported by Olson et al. (2012) (LAI = 8.4) and Ceotto et al. (2013) (LAI = 7.0-8.5). The high LAI resulted in greater light interception as shown by the relationship between LAI and FIPAR for I-405 and I-1990 (Fig. 7). Both I-405 and I1990 intercepted more than $90 \%$ of the incident PAR. A similar relationship was observed by Bégué (1993), Cieto et al. (2013), and Olson et al. (2012). As pointed out by Bégué (1993), plants with LAI > 4 intercept more than $90 \%$ of incident PAR. Maximum LAIs were reached 85 DAP. Thereafter LAI started to decline even though both hybrids maintained some green foliage up to the last harvest (148 DAP). According to Williams and Izaurralde (2013) the LAI of vegetative crops reaches a plateau at which time the rates of senescence and growth of leaf are approximately equal.

At Temple, the average light extinction $(k)$ values were 0.43 and 0.53 for I-405 and I-1990, respectively. Our values compare well with the values derived by Curt et al. (1998) $(k=0.57)$, Varlet-Grancher et al. (1992) $(k=0.59)$ and Perniola et al. (1996) $(k=0.62)$. A higher value of $k$ infers a higher incident PAR capture.

At HC \& S LAI values were comparably lower, with I-405 and I-1990 respectively reaching maximum LAIs of 4.5 and 3.0 at the last harvest (368 DAP) (Fig. 6b). The LAIs were significantly different $\left(P^{<0.01)}\right.$ at the first harvest (96 DAP) and last harvest 368 DAP), while at 172 DAP and 249 DAP there were non-significant. The increase in LAIs after dropping at 172 DAP was due to an increase in tillering.

\subsection{Plant growth rate (PGR)}

As expected, the computed PGRs (kg dry biomass $\mathrm{ha}^{-1}$ day- $^{1}$ ) from the data presented in Fig. 5 show that Temple had much higher PGRs than HC \& S. Even with the limited irrigation applied at Temple, the PGRs in $2012\left(153.20 \pm 20.91 \mathrm{~kg} \mathrm{ha}^{-1}\right.$ day- $\left.^{1}\right)$ were still lower than in $2013\left(224.96 \pm 24.76 \mathrm{~kg} \mathrm{ha}^{-1}\right.$ day- $\left.^{1}\right)$ due to the adverse drought conditions. The hybrid I-405 had a higher PGR $\left(200.81 \pm 24.50 \mathrm{~kg} \mathrm{ha}^{-1}\right.$ day- $\left.^{1}\right)$ than I-1990 (177.35 \pm 21.17 $\mathrm{kg} \mathrm{ha}^{-1}$ day- $^{1}$ ). As with the biomass yields PGRs at HC\&S were drastically lower than those at Temple. The PGR for I-405 and I-1990 prior to heading (96 DAP) were very much similar (41.65 $\pm 7.71 \mathrm{~kg} \mathrm{ha}^{-1}$ day- $^{1}$ and $40.44 \pm 10.01 \mathrm{~kg} \mathrm{ha}^{-1}$ day- $^{-1}$, respectively. Thereafter the PGRs were drastically reduced to an average of $8 \mathrm{~kg} \mathrm{ha}^{-1} \mathrm{day}^{-1}$. The low elevation field $718 \mathrm{had}$ a slightly higher 

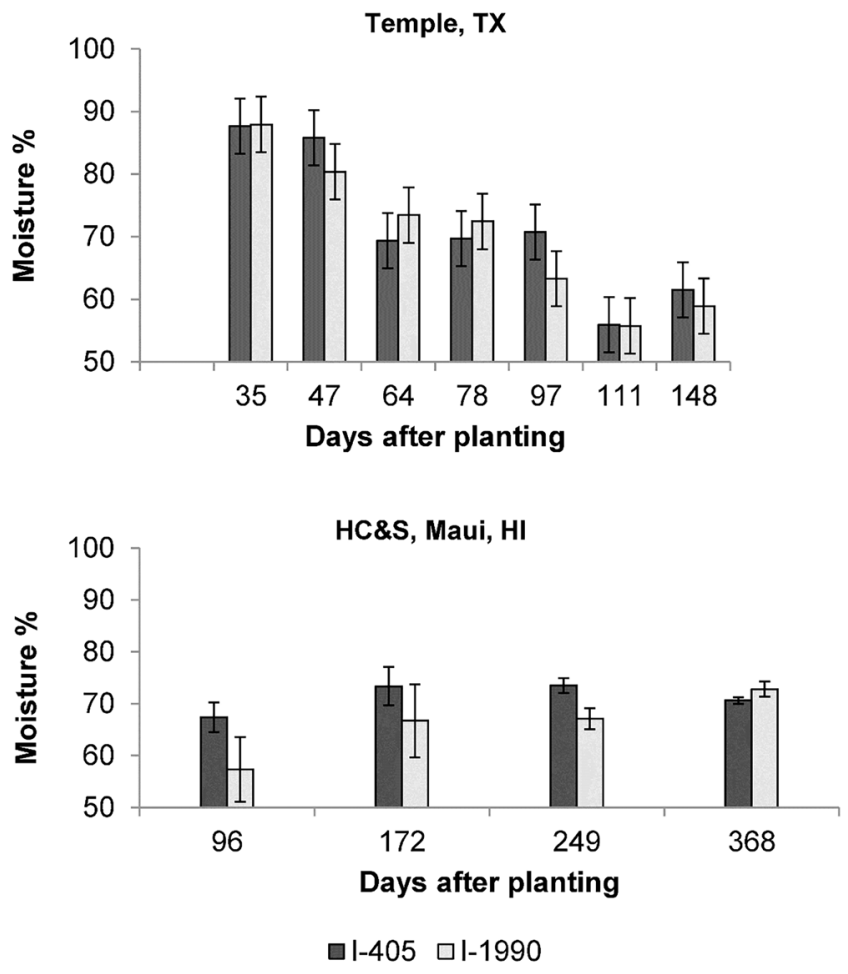

Fig. 8. (a) Biomass sorghum moisture content at each harvest date at Temple, TX and (b) fields (F) 410 and 718 at HC \& S, Maui, HI. Vertical bars represent the standard error of the means of the measured data.

overall biomass accumulation rate of $28 \mathrm{~kg} \mathrm{ha}^{-1} \mathrm{day}^{-1}\left(\mathrm{R}^{2}=0.79\right)$ due to the slightly warmer air temperature compared to the rate of $17 \mathrm{~kg} \mathrm{ha}^{-1} \mathrm{day}^{-1}\left(\mathrm{R}^{2}=0.56\right)$ for the high elevation field 410 . Not surprisingly, final dry biomass yields (368 DAP) for both hybrids were slightly higher in field 718 than in 410 (Fig. 5b).

The maturation of late maturing and photoperiod sensitive sorghum hybrids is regulated entirely by either thermal time accumulation (degree days) or daylength photoperiod triggers. According to Childs et al. (1997) daylength is the most important environmental factor that regulates flowering in sorghum genotypes. A thermal time accumulation trigger is found in grain sorghums in which maturity will only be reached after a specified accumulation of heat units. Photoperiod sensitive sorghums will not flower and hence produce high biomass through continued vegetative growth if sown when the daylength is more than the photoperiod trigger of $12 \mathrm{~h} 20 \mathrm{~min}$. However, growth in the more recently developed hybrids is regulated by a combination of varying degrees of both thermal time and day-length (Blade Energy Crops, 2010). The regulation of flowering time in sorghum genotypes has been widely studied and identified as being genetically and environmentally controlled (Childs et al., 1997; Murphy et al., 2011; Yang et al., 2014). According to Morgan and Finlayson (2000) the stage of plant development, daylength period, temperature, plant hormones such as gibberellins are all integrated to regulate flowering time in sorghum.

\subsection{Biomass moisture content}

Overall there were no statistically significant differences between I405 and I-1990 in biomass moisture contents (Fig. 8). At Temple, biomass moisture content reached a maximum of $88 \%$, 35 DAP, after which it started to decline, reaching an average of $60 \%$ at the last harvest (148 DAP). Interestingly, biomass moisture contents at HC \& S actually seemed to slightly increase at each harvest. The increase in biomass moisture content over the growing season could be associated with continued tillering over the growing season. Furthermore, there was little to no relationship between biomass moisture and rainfall/ temperature. Lower biomass moisture contents at harvest are highly recommended for reduced transportation costs and storage (Mohammed et al., 2014), and also ensure feedstock quality during storage (Rocateli et al., 2013).

\subsection{Radiation use efficiency (RUE)}

Radiation use efficiency varied from 2.39 to 3.04 at Temple (Fig. 9). The RUE values in 2012 were lower than those in 2013 partly due the lower biomass yields as a result of the drier 2012 season (Fig. 2). The average RUE of $2.75 \mathrm{~g} \mathrm{MJ}^{-1}$ is within the range of values for biomass sorghums reported by Rinaldi and Garofalo (2011) $\left(2.91 \pm 0.54 \mathrm{~g} \mathrm{MJ}^{-1}\right)$, and Olson et al. (2012), (2.2-2.3 $\left.\mathrm{g} \mathrm{MJ}^{-1}\right)$. Slightly higher RUE values have also been reported: $3.4 \mathrm{~g} \mathrm{MJ}^{-1}$ (Mastrorilli et al., 1995), $3.48 \mathrm{~g} \mathrm{MJ}^{-1}$ (Ceotto et al., 2013), $3.6 \mathrm{~g} \mathrm{MJ}^{-1}$ (Varlet-Grancher et al., 1992), and $3.55 \mathrm{~g} \mathrm{MJ}^{-1}$ (Dercas and Liakatas, 2007). According to Rinaldi and Garofalo (2011), RUE can vary depending on experimental conditions, especially the amount of crop available soil moisture and plant nutrients. Similarly, Demetriades-Shah et al. (1992) stressed that comparisons of RUE should only be made when measurements are made under similar conditions.

\section{Conclusion}

From a practical standpoint, the performance of the biomass sorghum hybrids used in this study was largely affected by the time of planting and daylength effects. At Temple, TX, the late maturing biomass sorghum hybrid I-405 and the photoperiod-sensitive hybrid I1990 were planted at the beginning of April when daylight hrs exceeded $12 \mathrm{~h} 20 \mathrm{~min}$. The two hybrids performed as expected: grew to heights in excess of $3 \mathrm{~m}$ and produced average biomass yields of 37.4 $\mathrm{Mg} \mathrm{ha}^{-1}$. At Temple, and for most other places on the continental USA, biomass sorghums should be planted when daylength hrs exceed of $12 \mathrm{~h}$ $20 \mathrm{~min}$, which allows the hybrids to continue growing vegetatively for longer periods (up to six months) before harvest. In Maui, HI, the biomass sorghum hybrids were planted in September when the daylength hrs were less than $12 \mathrm{~h} 20 \mathrm{~min}$, resulting in the hybrids flowering as early as 90 days after planting. For most grain crops, flowering diverts assimilates from the vegetative parts, primarily stems and leaves to the grain, resulting in low biomass accumulation and overall biomass yields. In the $\mathrm{HI}$ experiment, overall plant heights and biomass yields were reduced by $44 \%$ and $76 \%$, respectively. Not surprisingly, final dry biomass yields for both hybrids were slightly higher in the low elevation F718 than in the higher elevation F410 (Fig. 5b).

Crop parameter attributes for high biomass yields for the two hybrids planted at Temple indicated: high leaf area indices (LAI, 7.8-9.8) which intercepted over $90 \%$ incident PAR at LAI $>4$, and an average light extinction coefficient $(k)$, PGR, and RUE of 0.48 , $189 \mathrm{~kg}$ dry biomass $\mathrm{ha}^{-1}$ day- $^{1}$, and $2.75 \mathrm{~g} \mathrm{MJ}^{-1}$, respectively. In sharp contrast to the results obtained at Temple, the two sorghum hybrids planted on Maui had lower leaf area indices (average LAI, 3.8) and PGR prior to heading (average, $41 \mathrm{~kg} \mathrm{ha}^{-1} \mathrm{day}^{-1}$ ).

Besides determining crop parameter attributes and environmental factors for high biomass yields, the study provides valuable crop coefficients that can be incorporated into field and regional/watershed process-based models, such as ALMANAC, EPIC/APEX and SWAT to simulate biomass sorghum growth, and associated environmental impacts. These models can be used as tools for assessing the feasibility and potential sustainability of biomass sorghum biofuel feedstock cropping systems in various target environments. 


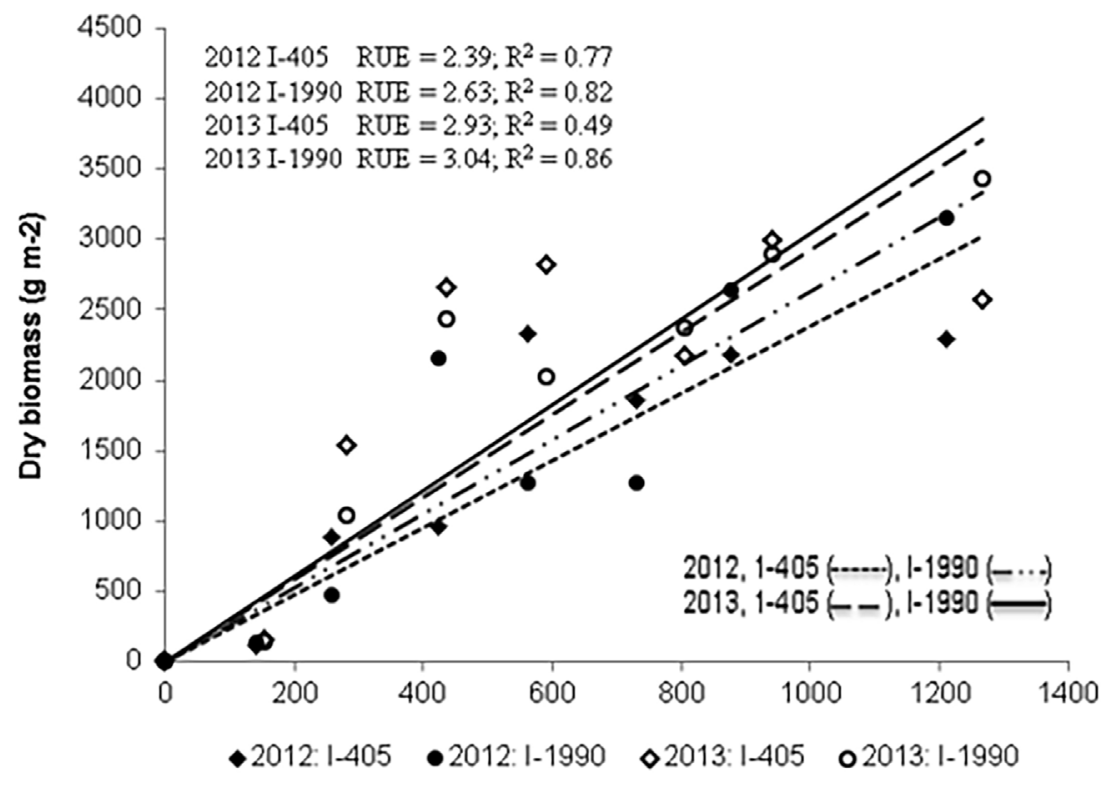

Cumulative IPAR (MJ m-2)

Fig. 9. Radiation use efficiency (RUE) of biomass sorghum hybrids I-405 and I-1990 at Temple, TX during the 2012 and 2013 growing seasons.

\section{Acknowledgements}

Preparation of this manuscript supported by the USDA-ARS, Grassland, Soil and Water Research Laboratory, and Texas A \& M AgriLife Research, Temple, TX, through Specific Cooperative Agreement: 58-6206-1-053, and was funded by the U.S. Navy, Office of Naval Research (ONR). This work was also partly funded by an ONR GrantN00014-12-1-0496 and USDE Award DE-FG36-08G088037 to the University of Hawaii. We appreciate the support by the USDA National Institute of Food and Agriculture: Hatch project TEX09514. Finally, we thank Jason Drogowski, Daniel Richardson and HC \& S staff for field work and research support. USDA is an equal opportunity provider and employer.

\section{References}

Alexander, A.G., 1985. The Energy Cane Alternative. Sugar Series \#6. Elsevier Science Publishing Co., Inc., New York.

Bégué, A., 1993. Leaf area index, intercepted photosynthetically active radiation, and spectral vegetation indices: a sensitivity analysis for regular-clumped canopies. Remote Sens. Environ. 45, 45-59.

Blade Energy Crops, 2010. Sorghum Management Guide. Managing High Biomass Sorghum as a Dedicated Energy Crop. http://www.bladeenergy.com/Bladepdf/ BladeSorghumMgmtGuide2010.pdf (Accessed 04 June 2016).

Carmi, A., Aharoni, Y., Edelstein, M., Umiel, N., Hagiladi, A., Yosef, E., Nikbachat, M., Zenon, A., Miron, J., 2006. Effects of irrigation and plant density on yield composition and in vitro digestibility of a new forage sorghum variety, Tal, at two maturity stages. Animal Feed Sci. and Technol. 131, 121-133.

Carpita, N.C., McCann, M.C., 2008. Maize and sorghum: genetic resources for bioenergy grasses. Trends Plant Sci. 13, 415-420.

Ceotto, E., Di Candiloa, M., Castellib, F., Badeck, F.W., Rizzad, F., Soave, C., Volta, A., Villani, G., Marletto, V., 2013. Comparing solar radiation interception and use efficiency for the energy crops giant reed (Arundo donax L.) and sweet sorghum (Sorghum bicolor L. Moench). Field Crops Res. 149, 159-166.

Childs, K.L., Miller, F.R., Cordonnier-Pratt, M.M., Pratt, L.H., Morgan, P.W., Mullet, J.E., 1997. The sorghum photoperiod sensitivity gene, $\mathrm{Ma}_{3}$ encodes a phytochrome $\mathrm{B}^{\prime}$ Plant Physiol. 113, 611-619.

Curt, M.D., Fernandez, J., Martinez, M., 1998. Productivity and radiation use efficiency of sweet sorghum [Sorghum bicolor (L.) Moench] cv. Keller in Central Spain. Biomass Bioenergy 14, 169-178.

Demetriades-Shah, T.H., Fuchs, M., Kanemasu, E.T., Flitcroft, I., 1992. A note of caution concerning the relationship between cumulated intercepted radiation and crop growth. Agric. For. Meteorol. 58, 193-207.

Dercas, N., Liakatas, A., 2007. Water and radiation effect on sweet sorghum productivity. Water Resour. Manag. 21, 1585-1600.

EPA (Environmental Protection Agency), 2015. Notice of Opportunity to Comment on the Lifecycle Greenhouse Gas Emissions for Renewable Fuels Produced from Biomass Sorghum. https://federalregister.gov/a/2014-30712 (Accessed 04 November 2016).
El Bassam, N., 2010. Handbook of Bioenergy Crops - A Complete Reference to Species. Development and Applications Earthscan Publ. London, Washington, DC.

Evans, L.T., 1993. Crop Evolution, Adaptation and Yield. Cambridge Univ. Press, Cambridge, UK.

Gaddis, N., 2013. Sugar Industry' Bitter Reality. Maui Now.com. http://mauinow.com/ 2012/07/24/the-sugar-industrys-bitter-reality/. (Accessed 15 April 2016).

Gerik, T.J., Neely, C.L., 1987. Plant density effects on main culm and tiller develop-ment of grain sorghum. Crop Sci. 27, 1225-1230.

Gutjahr, S., Vaksmann, M., Dingkuhn, D., Thera, K., Trouche, G., Braconnier, S., Luquet, D., 2013. Grain, sugar and biomass accumulation in tropical sorghums: I. Trade-offs and effects of phenological plasticity. Funct. Plant Biol. 40, 342-354.

Habyarimana, E., Bonardi, P., Laureti, D., Di Bari, V., Cosentino, S., Lorenzoni, C., 2004a Multilocational evaluation of biomass sorghum hybrids under two stand densities and variable water supply in Italy. Indust. Crops Prod. 20, 3-9.

Habyarimana, E., Laureti, D., De Ninno, D., Lorenzoni, C., 2004b. Performance of biomass sorghum [Sorghum bicolor (L.) Moench] under different water regimes in Mediterranean region. Indust. Crops Prod. 20, 23-28.

Hawaii State Energy Office, 2015. Hawaii Energy Facts \& Figures, May 2015 Edition. http://energy.hawaii.gov/wp-content/uploads/2011/10/HSEO FF May2015.pdf (Accessed 05 November 2016).

Kinoshita, C.M., Stackmann, M., 1994. Hawaii Energy Strategy Development, Project 5: Transportation Energy Strategy, Prepared for Parsons, Brinckerhoff, Quade and Douglas, Inc. and State of Hawaii, Department of Business, Economic Development and Tourism; Energy Division. Hawaii Natural Energy Institute.

Kinoshita, C., Zhou, J., 1999. Siting Evaluation for Biomass-Ethanol Production in Hawaii. National Renewable Energy Laboratory, Oak Ridge, TN.

Mastrorilli, M., Katerji, N., Rana, G., Steduto, P., 1995. Sweet sorghum in Mediterranean climate: radiation use and biomass water use efficiencies. Ind. Crops Prod. 3, 253-260.

Maughan, M., Voigt, T., Parrish, A., Bollero, G., Rooney, W., Lee, D.K., 2012. Forage and energy sorghum responses to nitrogen fertilization in Central and Southern Illinois. Agron. J. 104, 1032-1040.

Meki, N.M., Kiniry, J.R., 2013. A Dynamic Tool - Resource Assessment Framework for Dependable Feedstock Supply to Produce Advanced Biofuels in Hawaii. International Innovation: The Global Forecast, October 2013. Research Media, UK, pp. 118-120 (ISSN 2051-8544).

Meki, N.M., Kiniry, J.R., Youkhana, A.H., Crow, S.E., Ogoshi, R.M., Nakahata, M.H., Tirado-Corbalá, R., Anderson, R.G., Osorio, J., Jeong, J., 2015. Two-year growth cycle sugarcane crop parameter attributes and their application in modeling. Agron. J. 107, 1310-1320.

Miller, F.R., McBee, G.G., 1993. Genetics and management of physiological systems of sorghum for biomass production. Biomass Bioenergy 5, 41-49.

Mohammed, A.Y., Chengci, C., Lee, D.K., 2014. Harvest time and nitrogen fertilization to improve bioenergy feedstock yield and quality. Agron. J. 106 (1), 57-65.

Monsi, M., Saeki, T., 1953. Uber den Lichtfaktor in den Pflanzengesellschaftenund sein Bedeutung fur die Stoffproduktion. J. Jpn. Bot. 14, 22-52.

Morgan, P.W., Finlayson, S.A., 2000. Physiology and genetics of maturity and height. In: Smith, C.W., Frederiksen, R.W. (Eds.), Sorghum: Origin, History, Technology, and Production. Wiley Series in Crop Sci., New York, pp. 240-242.

Murphy, R.L., Klein, R.R., Morishige, D.T., Brady, J.A., Rooney, W.L., Miller, F.R., Dugas, D.V., Klein, P.E., Mullet, J.E., 2011. Coincident light and clock regulation of pseudoresponse regulator protein 37 (PRR37) controls photoperiodic flowering in sorghum. Proc. Natl. Acad. Sci. U. S. A. http://dx.doi.org/10.1073/pnas. 
1106212108.

Olson, S.N., Ritter, K., Rooney, W., Kemanian, A., McCarl, B.A., Zhang, Y., Hall, S., Packer, D., Mullet, J., 2012. High biomass yield energy sorghum Developing a genetic model for C4 grass bioenergy crops. Biofuels Bioprod. Biorefin. 6, 640-655.

Perniola, M., Tartaglia, G., Tarantino, E., 1996. Radiation use efficiency of sweet sorghum and kenaf under field condition (abstr.). In: 9th European Bioenergy Conference. 24-27 June 1996, Copenhagen Denmark. Pergamon/Elsevier Publishers. (pp.156).

Ra, K., Shiotsu, F., Abe, J., Morita, S., 2012. Biomass yield and nitrogen use efficiency of cellulosic energy crops for ethanol production. Biomass Bioenergy 37, 330-334.

Rinaldi, M., Garofalo, P., 2011. Radiation-use efficiency of irrigated biomass sorghum in a Mediterranean environment. Crop Pasture Sci. 62, 830-839.

Rocateli, A.C., Raper, R.L., Balkcom, K.S., Arriaga, F.J., Bransby, D.I., 2012. Biomass sorghum production and components under different irrigation/tillage systems for the southeastern U.S. Ind. Crops Prod. 36, 58-9598.

Rocateli, A.C., Raper, R.L., Olander, B., Pruitt, M., Schwab, E.B., 2013. Rapidly drying sorghum biomass for potential biofuel production. Agric. Eng. Int.: CIGR J. 15, 43-49.

Rooney, W.L., Blumenthal, J., Bean, B., Mullet, J.E., 2007. Designing sorghum as a dedicated bioenergy feedstock. Biofuels Bioprod. Biorefin. 1, 147-157.

SAS Institute, 2011. SAS System Version 9.3. SAS Inst., Cary, NC.

Sakellariou-Makrantonaki, M., Papalexis, D., Nakos, N., Kalavrouziotis, I.K., 2007. Effect of modern irrigation methods on growth and energy production of sweet sorghum (var: Keller) on a dry year in Central Greece. Agric. Water Manage. 90, 181-189.

Sarath, G., Mitchell, R.B., Sattler, S.E., Funnell, D., Pederson, J.F., Graybosch, R.A., Vogel, K.P., 2008. Opportunities and roadblocks in utilizing forages and small grains for liquid fuels. J. Ind. Microbiol. Biotechnol. 35, 343-354.

Smith, G.A., Bagby, M.O., Lewellan, R.T., Doney, D.L., Moore, P.H., Hills, F.J., Campbell, L.G., Hogaboam, G.J., Coe, G.E., Freeman, K., 1987. Evaluation of sweet sorghum for fermentable sugar production potential. Crop Sci. 27, 788-793.

Snider, L.J., Raper, R.L., Schwab, E.B., 2011. The effect of row spacing and seeding rate on biomass production and plant stand characteristics of non-irrigated photoperiod- sensitive sorghum (Sorghum bicolor (L.) Moench). Ind. Crops Prod. 37, 527-535.

Tsuni, Y., Fujisi, K., 1965. Studies on the dry matter production of sweet potato. Crop Sci. Soc. Japan Proc. 33, 230-235.

US DOE, 2015. Hawaii Clean Energy Initiative (HCEI). Office of Electricity Delivery \& Energy Reliability. http://energy.gov/oe/services/electricity-policycoordination-and-implementation/state-and-regional-policy-assistanc-2 (Accessed 19 May 2016).

USDA NRCS, 2011. Spatial and Tabular Data of the Soil Survey for Maui, Hawaii. USDA. http://energy.gov/oe/services/electricity-policy-coordination-and-implementation/ state-and-regional-policy-assistanc-2 (Accessed 19 May 2016).

Undersander, D.J., Smith, L.H., Kaminski, A.R., Kelling, K.A., Doll, J.D., 1990. Alternative Field Crops Manual. https://www.hort.purdue.edu/newcrop/afcm/forage.html (Accessed 25 May 2016).

Varlet-Grancher, C., Chartier, M., Lemaire, G., Grosse, G., Bonhomme, R., Cruz, P., Castal, F., Lenoble, S., 1992. Productivity of sweet sorghum compared to Sudan-grass and sorghum Sudan-grass hybrids: radiation interception and biomass accumulation under non limiting water and nitrogen condition. In: Grassi, A., Collina, H., Zibetta, H. (Eds.), Proc. 6th EC Conf. Biomass for Energy Industry and Environ. Elsevier Applied Science : Oxford. U.K.. pp. 265-267.

Venuto, B., Kindiger, B., 2008. Forage and biomass feedstock production from hybrid forage sorghum and sorghum-sudangrass hybrids. Grassland Sci. 54, 189-196.

Williams, J.R., Izaurralde, R.C., 2013. APEX Theoretical Documentation. Texas A \& M AgriLife Research. Blackland Research and Extension Center, Temple, Texas. http:// epicapex.tamu.edu/files/2013/02/the-apex-theoretical-documentation.pdf (Accessed 20 May 2016).

Yang, S., Weers, Y.B.D., Morishige, D.T., Mullet, J.E., 2014. CONSTANS is a photoperiod regulated activator of flowering in sorghum. BMC Plant Biol. 14, 148. http://dx.doi. org/10.1186/1471-2229-14-148.

Zadoks, J.C., Chang, T.T., Konzak, C.F., 1974. A decimal code for the growth stages of cereals. Weed Res. 14, 415-421. 